\title{
Prediction Approach for Petrothermal Properties in Al Hashimiyya Basalts-Jordan
}

\author{
Sana'a Al-Zyoud \\ Department of Applied Earth and Environmental Sciences, Institute of Earth and Environmental Sciences, Al al-Bayt University, \\ Al Mafraq, Jordan \\ Email: al-zyoud@aabu.edu.jo
}

How to cite this paper: Al-Zyoud, S. (2019) Prediction Approach for Petrothermal Properties in Al Hashimiyya Basalts-Jordan. Open Journal of Geology, 9, 43-56. https://doi.org/10.4236/ojg.2019.91004

Received: January 1, 2019

Accepted: January 26, 2019

Published: January 29, 2019

Copyright (c) 2019 by author(s) and Scientific Research Publishing Inc. This work is licensed under the Creative Commons Attribution International License (CC BY 4.0).

http://creativecommons.org/licenses/by/4.0/

\section{(c) (i) Open Access}

\begin{abstract}
Thermal conductivity and mineral composition of flood basalt in Al Hashimiyya city were correlated. Representative thin sections were optically analyzed for their mineral constituents and micro fractures. Findings of this study will contribute to a comprehensive understanding of the correlation between selected petrological characteristics of basalts and their heat conduction properties. It found that a $10 \%$ increase of opaque and ferromagnesian minerals volume in the studied basalts leads to a thermal conductivity increasing by $0.4 \mathrm{~W} \cdot \mathrm{m}^{-1} \cdot \mathrm{K}^{-1}$. This may considerably contribute to provide an alternative to direct measurements of the thermal conductivity in Jordan basalts if a sufficient mineralogical data set is achievable. Thus, the prediction of thermal conductivity through modal mineral composition may become a significant feature for efficient geothermal system exploration in basaltic rocks. The results can be brought together into a petrophysical and hydrogeothermal model for better reservoir characterization. Such models will improve the assessment of the basalt's suitability as a geothermal reservoir for cooling and heating utilizations.
\end{abstract}

\section{Keywords}

Thermal Conductivity Prediction, Ferromagnesian Minerals, Flood Basalts, Al Hashimiyya, Jordan

\section{Introduction}

The Mediterranean region has a strong interest in applying innovative and environmentally non-conventional energy resources such as geothermal energy; accordingly, the most effective utilization of geothermal energy in Jordan is for cooling purposes. This study presents a new conceptual framework for predict- 
ing thermal conductivity of basalts based on their mineral constituents. An arithmetic formula has been developed to correlate thermal conductivity with opaque and ferromagnesian minerals. This development has reliance on three assumptions: isotropic chemical composition, random oriented crystals and homogenous basaltic sub-flows. This formula has been applied to the available data to approve whether it is a reliable prediction method or not. Such formula can be applied during the primary stages of geothermal systems exploration. Yet, petrothermal properties have not been investigated in the Jordanian basalts. Petrothermal properties should be determined with other petrophysical properties in one comprehensible approach in early stages of geothermal exploration. A new petrothermal model, where thermal conductivity is dependent on mineral volume proportional, mineral crystal size and microstructure, may initiate such an approach. In geothermal potential preliminary studies a detailed mineralogical analysis will increase the exploration precision and reliability. The scientific motivation for this study arises from this fact.

[1] stated that thermal conductivity is an essential criterion for the calculation of heat flow models, he established a new geometric model correlating thermal conductivity with mineral composition of water saturated basalt fragments. In addition, permeability is other unique key parameter for characterizing the geothermal reservoir [2]. Different models have earlier been established to calculate thermal conductivity based on various petrophysical properties: porosity, density, P-wave velocity, uniaxial compressive strength as input parameters (e.g. [3]; [4]; [5]; [6]).

[7] established a numerical model for thermal conductivity in crystalline rocks, dependent on their volumetric mineral proportions. He concluded that the crystal orientation and size causes differences in thermal conductivity between $2 \%$ and $3 \%$. [8] found that the measured thermal properties of the sedimentary rocks in Scanian rock types, Sweden are widely range values in related to their physical properties. [9] compared the results of measured thermal properties of different types of rocks in Italy to the calculated thermal conductivities predicted by applying Hashin and Schtrickman method [10]. He investigated the applicability of this method for a mineral aggregate in combination with the Zimmerman's model that takes porosity into account to calculate the bulk thermal conductivity [11]. The results of the above mentioned studies are limited to rock varieties of a restricted geographic region and geological setting. [12] found that the thermal conductivity increases with the olivine mineral volume proportion in Hawaiian basaltic rocks.

$\mathrm{Al} \mathrm{Hashimiyya} \mathrm{basalt} \mathrm{is} \mathrm{part} \mathrm{of} \mathrm{a} \mathrm{sequence} \mathrm{of} \mathrm{large} \mathrm{intra-continental} \mathrm{flood} \mathrm{ba-}$ salts [13]. These basalt flows cover the gentle slopes of the northern Jordanian desert ends with a small extension to the west. These basalts are hydraulically connected with the underlay limestone formations, and together represent a shallow groundwater aquifer in the Amman Zarqa basin [14].

However, the results of some investigations on Mid-Ocean Ridge Basalts (MORB) basalts ([15]; [16]) could not be applied on the Jordanian continental 
flood basalts. This is because of the distinct differences between MORB and continental flood basalts in occurrences, generation process and tectonic settings [17].

Investigations to predict thermal conductivity may suggest cost-effective opportunities to gain data transferrable to geothermal systems of homogenous flood basalts at greater depths. Evidently, this equation is expected to improve modeling software for flood basalts, which are essential for geothermal exploitation.

\section{Geologic settings}

The magmatic activity within the Arabian plate occurred from the Miocene to sub-recent time and produced several basaltic flows. Al Hashimiyya basalts are part of the Cenozoic continental basaltic rocks known as Harrat Al-Shaam (Figure 1) covering an area of ca. $12,000 \mathrm{~km}^{2}$ [18].

[19] concluded that the basalts of Jordanian Harrat resulted from six major basalt flows (named B1-B6) and one eruption of tephra (assigned as B't). Basaltic flows B1-B3 are not exposed in Jordan, but are known from borehole data [20]. [21] suggested a new classification based on more detailed K-Ar dating. They subdivided the volcanics into three major episodes: Oligocene to early Miocene (26 - $22 \mathrm{Ma})$, middle to late Miocene (13 - $8 \mathrm{Ma}$ ), and late Miocene to Pleistocene ( $7 \mathrm{Ma}$ to $<0.1 \mathrm{Ma}$ ). Basalts in the study area belong to youngest eruption phase with an age of $3.7-0.1 \mathrm{Ma}$ [21]. Abed Olivine Phyric basalt formation is the main basaltic flow in the study area [22]. Basalts of ca. $400 \mathrm{~m}$ thickness of successive flows are found in the NE part of the study area, while less than $100 \mathrm{~m}$ is found in the southern parts of the study area [20]. The basalts are lithologically well distinguished, and structurally typically developed. It is easy to identify each basalt flow from its special lithology and primary magmatic structures. The study area section is about $10 \mathrm{~km}$ northern Zarqa city, it locates at latitude of $32^{\circ} 08^{\prime} 50^{\prime \prime} \mathrm{N}$ and longitude of $36^{\circ} 05^{\prime} 15^{\prime \prime} \mathrm{E}$. The basalts extrusions parallels to the Wadi Sirhan fault system extending NW-SE (Figure 1). For this study's purposes, one main flow northern Al Hashimiyya city was selected after consideration of several determining criteria such as: 1) location as it's the south western extinction end of basaltic flow in the region, 2) the accessibility of the outcrops, 3) structural aspects of presenting moderate (upper sub-flows) to low (lower sub-flows) joints and fractures, 4) basalt alteration and weathering is uncommon under microscope as in the other flows in the eastern area [23]. The main flow was composed of six sub-flows separated from each other by zones of highly vesicular rocks at the top of each flow. The total thickness is about $37 \mathrm{~m}$, the top sub-flow locates at elevation of $549 \mathrm{~m}$ a.s.l while the lowest sub-flow locates at $512 \mathrm{~m}$ a.s.l. The upper two sub-flows are characterized with orthogonal cooling fissures and humpy ridges structure. A blocky structure is exhibited by the middle and the lower sub-flows. Al Hashimiyya flow is characterized by tectonic fractures (parallel with the preferred orientation of main fault system of NW-SE direction) and the first two sub-flows exhibit the cooling joints very distinguished. 


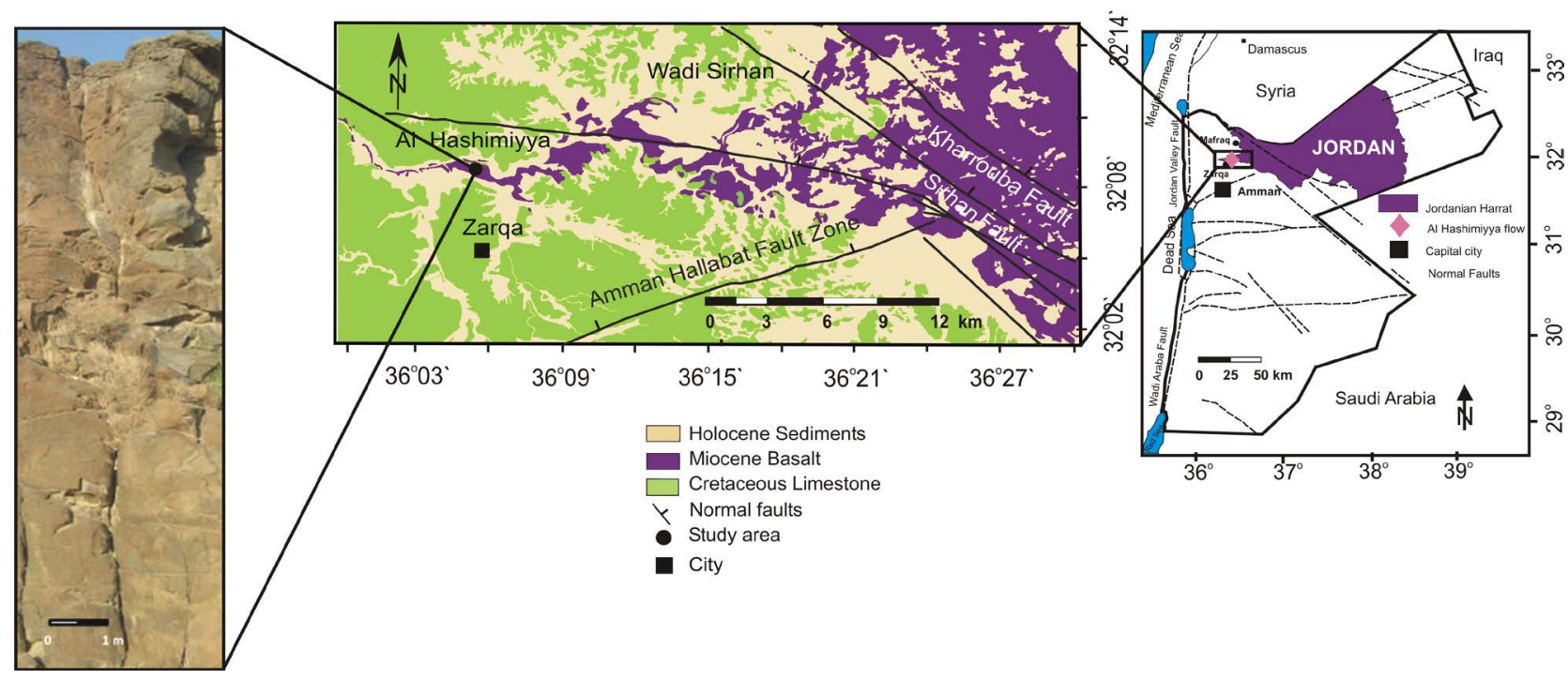

Figure 1. Right: Location map of the study area (Jordanian Harrat after [18]). Middle: Geological map of the study area (after [22]). Left: The upper $10 \mathrm{~m}$ of the studied section.

\section{Methods}

Thermal conductivity measurements were conducted under standard laboratory conditions on oven dried core samples. Thermal conductivities were measured using the Optical Scanning Method [24].

This method is based on sample surface (flat or curved) scanning with a movable, direct, and constantly run heat $\left(4^{\circ} \mathrm{C}\right)$ source accompanied with a temperature sensor (Figure 2). Such apparatus considered to be a reasonably quick thermal conductivity measuring device. Different sample types, nonetheless the thermal conductivity anisotropy, can be measured. The measuring concept is as follows; the movable heat source (of about $1 \mathrm{~mm}$ diameter) is scanning and heating the sample surface with no direct physical contact between the sample and the heat source. Parallel with this movement, a temperature sensor (with fixed distance a part from the heat source) move together with the heat source in a constant speed.

Thermal conductivity of the examined sample is calculated as the arithmetic mean of local conductivities of the successive measurements on the sample surface. These measurements are controlled by before and after heating measurements for the scanned sample. Two standards with known thermal conductivities are located prior and after the sample on the scan line. The standards are made from a material has a thermal conductivity $\left(\lambda_{R}\right)$ close to the sample thermal conductivity. The comparison between the examined sample and the induced temperature differences of the standards will conclude the sample thermal conductivity $\lambda$ (Equation (1)) with an accuracy of 3\%. The ratio of temperature rise for standard and sample $\Theta_{R}$ and $\Theta$ is proportional to the measured electrical potential for both samples $U_{R}$ and $U$, this is described as follows [24];

$$
\lambda=\lambda_{R}\left[\frac{\Theta_{R}}{\Theta}\right]=\lambda_{R}\left[\frac{U_{R}}{U}\right]
$$




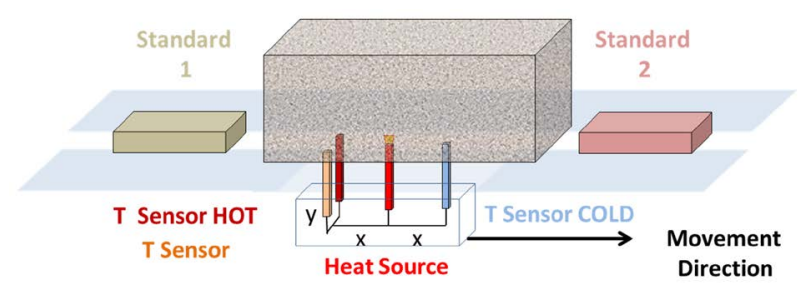

Figure 2. Thermal conductivity scanner measuring concept.

The mineralogical analysis was conducted under a polarized light microscope. Point counting approach was applied to establish modal proportion. Thin sections were prepared in stand dimensions of $30 \mathrm{~mm} \times 20 \mathrm{~mm} \times 30 \mu \mathrm{m}$. Petrographical properties and micro-textures of these samples were studied under polarized light microscope. In addition, a modal analysis was performed by counting points on a special lence such use. A total of 24 representative thin sections were selected from all basalt sub-flows from Al Hashimiyya basalts. For every slide approximately 400 points were counted for phenocrysts and groundmass coverage.

On the other hand, X-ray fluorescence spectrometry was directed for basalts chemical analysis. Correlations between thermal conductivity mineral proportions were performed and expressed in an arithmetic function.

\section{Results}

1) Mineral analysis

The studied basalts are relatively uniform in their mineralogical composition. They are characterized by plagioclase, pyroxene, olivine and opaque mineral constituents. This indicates early crystallization of magma differentiation stages and continental contamination. The slight olivine content in this basalt indicates a compositional deviation to andesite-trachy basalt (Figure 3). Opaque minerals are crystallized in large size and amount. According to alkali feldspar-plagioclase-feldspathoid constituents, the analysed rock is basalt to foid-bearing basalt composition [25]. In addition, [26] classification of rocks indicates that the magma had experienced moderate fractionation of olivine and plagioclase.

The difference in major elements shows a mafic-ultramafic source (also $\mathrm{Cr}$, $\mathrm{Co}, \mathrm{Ni}$ ) with K-poor continental contamination (deduced also from the $\mathrm{Rb} / \mathrm{Sr}$ relation and $\mathrm{Ba}$ content). This indicates that the basalts are of alkaline chemical type (alkali-olivine basalts with a shift to the sodic series).

Based on modal analyses the studied basalts are classified as plagioclase, pyroxene, olivine-phyric vesicular basalt. In general, $80 \%$ of thin sections exhibit micro-doleritic texture (about $1 \mathrm{~mm}$ crystal length) while $20 \%$ shows fine grain (less than $1 \mathrm{~mm}$ length). Rarely, some crystals exceed $3 \mathrm{~mm}$ in length. Moreover, most sub-flows show fine porphyritic texture with quite homogeneous petrography characteristics; e.g. glomeroporphyritic intergrowth, felty orientation, poikilitic and absorbed crystals. As the common texture is micro-doleritic, the point counting is adequate to differentiate between all mineral phases. X-ray 


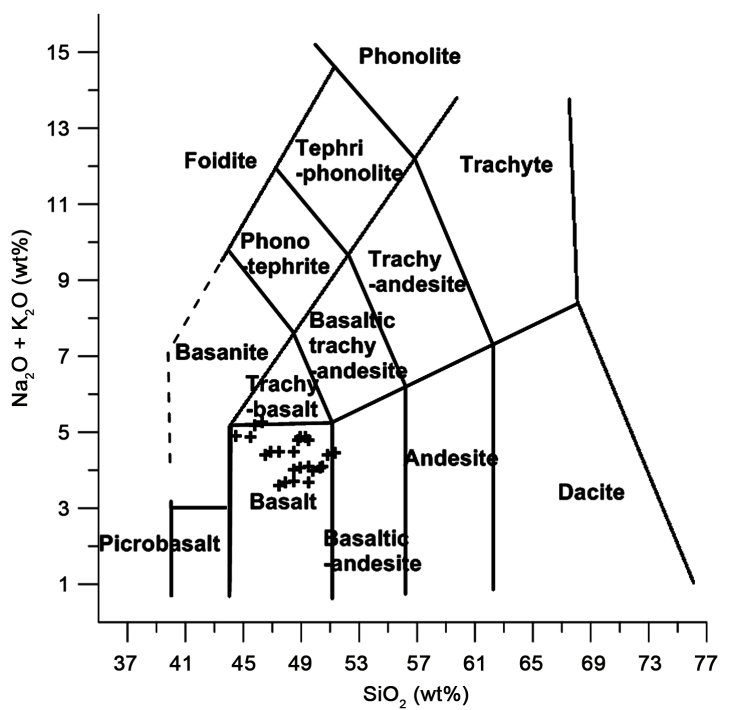

Figure 3. Total Alkali Silica (TAS)-diagram [22] for the studied basalts.

fluorescence analysis was accompanied together with the mineral composition analysis.

a) Plagioclase and K-feldspar

Plagioclase is crystallized in two generations; dominant fine size (microlites) of groundmass with some lath-like phenocrysts (Figure 4(a)). Plagioclase ranges in length from $0.05 \mathrm{~mm}$ to $3 \mathrm{~mm}$. Multiple twining is common. Some obvious orientations of plagioclase crystals were noted partially in some samples. Plagioclase laths were found to have an extinction angle between $32^{\circ}$ to $40^{\circ}$, indicating a labradorite $\left(\mathrm{Ab}_{50}-\mathrm{An}_{50}\right)$ composition. Plagioclase and pyroxene crystals exhibit sub-ophitic to ophitic textures. High temperature K-feldspar porphyritic phenocrysts indicate together with some chemical shifts $\left(\mathrm{Al}_{2} \mathrm{O}_{3}, \mathrm{Na}_{2} \mathrm{O}\right)$ a slight contamination of the utramafic source. Due to the low $\mathrm{K}$ content and relatively high Na, K-feldspar of Anorthoclase composition is expected.

b) Pyroxene

Pyroxene crystals exhibit two sets of fair to good cleavage intersecting at about $90^{\circ}$. The dominant mineral component is augite of clinopyroxene type. Orthopyroxene is displayed as enstatite end-member composition. Crystals appear as one generation (phenocrysts) ranging in size from 0.35 to $2.5 \mathrm{~mm}$ (Figure 4(b)). Clinopyroxene crystals have an inclined extinction angle between $34^{\circ}-49^{\circ}$, which indicates an augite mineral composition. The crystals also show a clear alteration visible as green pleochroitic Fe-Mg-chlorite on the fractures, crystal rims, and on the cleavage sets. It is a relative dry alteration because talc and serpentine is not found.

c) Olivine

Olivine is characterized by early crystallized, isometric phase (Figure 4(c)) with resorbtion and alteration texture in the groundmass in all sub-flows. The shape of resorbed olivine crystals is noted through bands of iddingzite that form along embayment rims, fractures and rarely complete iddingsitation. The 


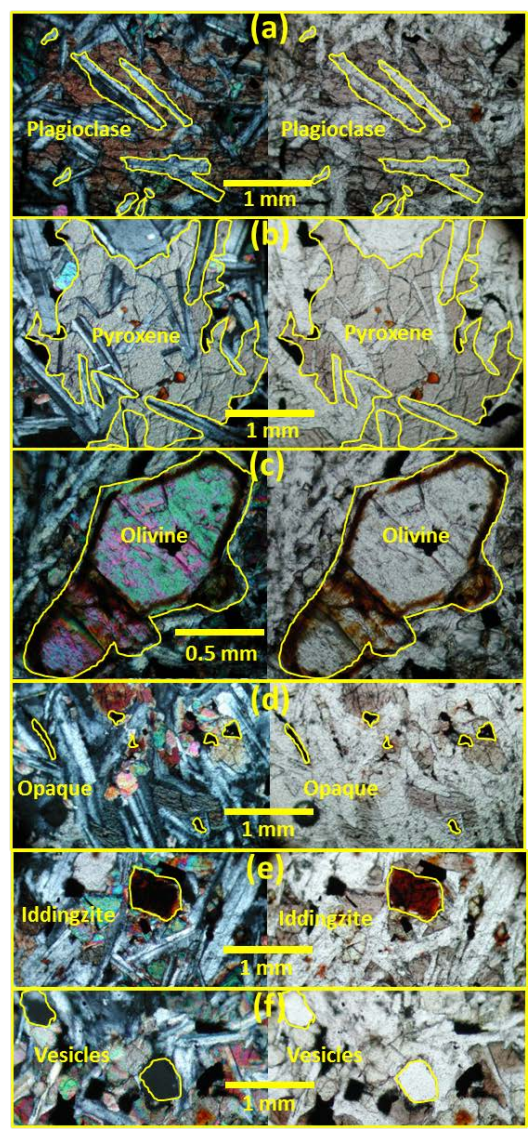

Figure 4. Mineral constituents in the studied basalts (left; Crossed Polarized Light, right; Plane Polarized Light).

common composition is forsterite composition $\left(\mathrm{Fo}_{85-90}\right)$ was determined. The crystals range in size from $0.01 \mathrm{~mm}$ to $0.3 \mathrm{~mm}$ in all sub-flows. Some crystals include euhedral to anhedral opaque grains inclusions. However, all basalt sub-flows show some corroded olivine crystals.

d) Opaque minerals

Opaque minerals mainly magnetite $\left(\mathrm{Fe}_{2} \mathrm{O}_{3}\right)$ are common in all flows as inclusions in pyroxene and olivine and as intra-crystals. Opaques range in size from $0.03 \mathrm{~mm}$ to $0.5 \mathrm{~mm}$ (Figure 4(d)). Much smaller fine lath and bipyramidal crystals are observed in the groundmass. These minerals are too small for a precise identification.

e) Secondary minerals

Several secondary (authogenic) minerals formed due to the hydration and oxidation of the pyrogenic minerals. These alteration processes include labradorite seritisation [27], olivine iddingsitisation (Figure 4(e)) and pyroxene chloritisation. The studied samples exposed to low to moderate degree of chloritization on clinopyroxenes like augite. Two types of calcite can be distinguished. The first type is uniquely comprised of spot-like patches of calcite as interstitial crystals. The other type of calcite was precipitated in vesicles. Due to post-eruption alteration processes, this calcite presents the amygdaloidal texture. This type 
represents the late calcite precipitation.

\section{f) Vesicles}

The vesicularity of the basalts averages $10 \%$ and ranges from 8 to 12 vol\% in all sub-flows (Figure 4(f)), some vesicles are partly filled with calcite resulted amygdaloidal texture. The total porosity ranges from $6.5 \%$ to $11.8 \%$ and averages $10.7 \%$. The difference between the porosity measured in thin sections (vesicularity) and the total porosity measured in the laboratory is expected. The variation is explained through the larger size limit of vesicle diameter which is distinguishable under the microscope. Petrographically, this limit is assumed to be 30 $\mu \mathrm{m}$ in diameter which is equal to the thin section thickness. Whereas the total porosity measured in the lab detects all vesicles, including macro and micro-pores, leading to this discrepancy [16]. In addition, if we consider the total porosity is of primary type, then micro-fractures could be considered as secondary porosity.

The resulting mineral proportions are examined regarding their possible influence on thermal conductivity of the studied basalts.

2) Correlation between thermal conductivity and mineral volume proportions

The correlation between plagioclase, (the most abundant mineral), and thermal conductivity of the studied basalts is poor. The coefficient of determination was found to be $\left(\mathrm{R}^{2}\right)$ is 0.03 .

Thermal conductivity and opaques with ferromagnesian minerals are positively correlated over all investigated basalts sub-flows (Figure 5). Upper and lower limits show 3\% error bar. It can be proved that the abundance of ferromagnesian minerals (olivine; $\mathrm{Fo}_{85-90}$, pyroxene; enstatite, augite e.g. Fe, $\mathrm{Mg}$-rich

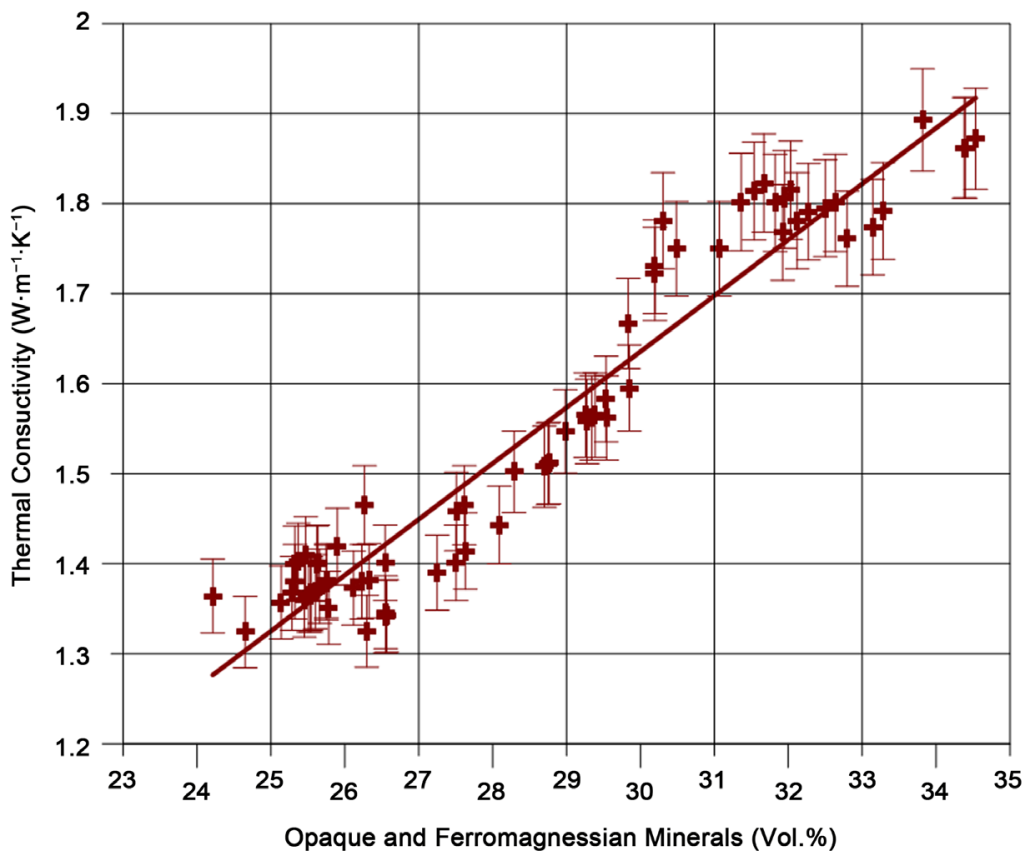

Figure 5. Correlation between thermal conductivity and ferromagnesian with opaque minerals; $\mathrm{R}^{2}$ is 0.93 . 
ferroaugite and opaque minerals mainly magnetite $\left.\left(\mathrm{Fe}_{3} \mathrm{O}_{4}\right)\right)$ directly control basalt thermal conductivity. It found that a $10 \%$ increase of opaque and ferromagnesian minerals volume in the studied basalts leads to a thermal conductivity increasing by $0.4 \mathrm{~W} \cdot \mathrm{m}^{-1} \cdot \mathrm{K}^{-1}$. This study derived an arithmetic function representing this interrelation (Equation (2)). This function is applicable for the Alkali flood basalts. The total opaques and ferromagnesian minerals in alkali basalts are $>10 \%$ [28]. This function shows a high statistical significance $\mathrm{R}^{2}$ of 0.93 .

$$
\lambda_{H}=0.062 n_{O F M}-0.22
$$

where;

$\lambda_{H}$ : Thermal conductivity $\left(\mathrm{W} \cdot \mathrm{m}^{-1} \cdot \mathrm{K}^{-1}\right)$ of $\mathrm{Al}$ Hashimiyya basalt and $n_{O F M}$ : opaque and ferromagnesian minerals volume proportion.

This equation integrates the proportion of minerals of iron and magnesium composition ( $\mathrm{MgO}$ minerals as forsterite and enstatite are included), whereas other rock-forming minerals are not considered. This is in accord with [12], who found that the increase of the olivine mineral volume proportion in Hawaiian basaltic rocks leads to an increase of thermal conductivity.

In addition, [23] investigated thermal conductivity of continental basalt from Vogelsberg in eastern upper Hesse-Germany and oceanic basalt from Iceland were investigated into their influenced by mineral proportions. The results of this study were compared with the previous findings (Figure 6) and prove the main conclusion of basalt's thermal conductivity dependence on opaque and ferromagnetic mineral proportion. This is indicated by the following functions correlate thermal conductivity with opaque and ferromagnetic mineral volume proportions under predefined uncertainties.

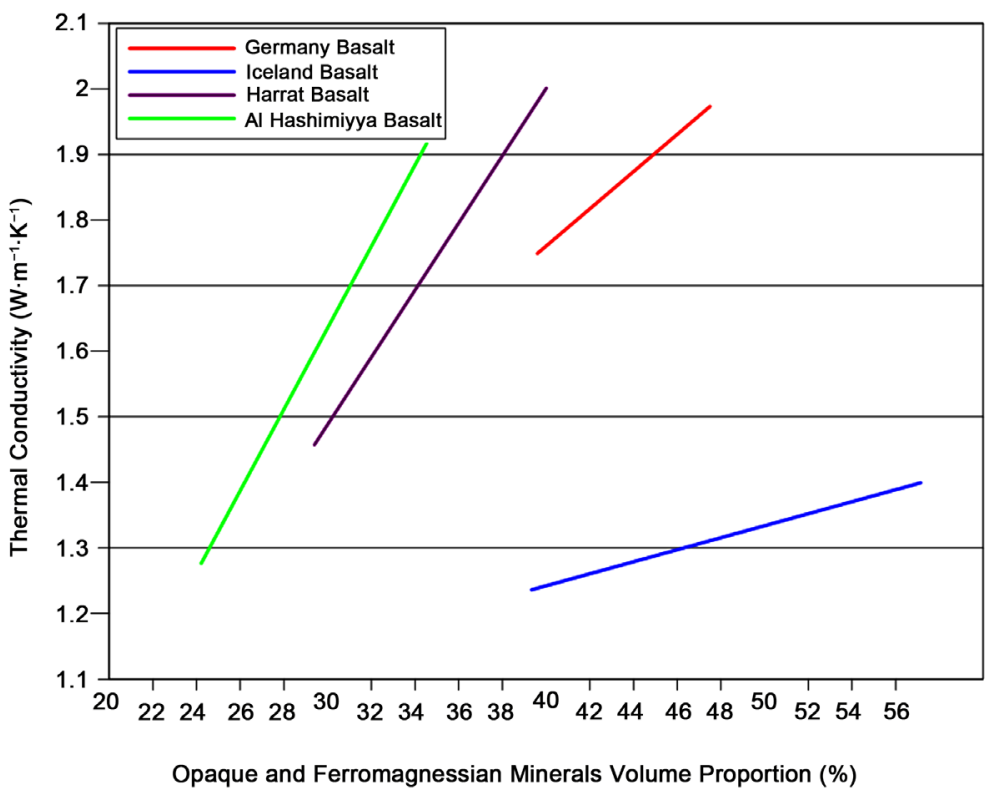

Figure 6. Correlation between thermal conductivity and opaque with ferromagnesian minerals for Germany, Iceland and Jordan basalts; NE Harrat and Al Hashimiyya basalts. 
The coefficient of determination $\left(R^{2}\right)$ is $0.40,0.63,0.92$ for German, Icelandic and Jordanian Harrat basalts respectively. The correlated mathematical formulas (Equations (3)-(5)) are illustrated bellow;

$$
\lambda_{G}=0.01 n_{\text {OFM }}-0.88
$$

where;

$\lambda_{G}$ : Thermal conductivity of the German basalts and $n_{O F M}$ : opaque and ferromagnetic minerals volume proportion.

$$
\lambda_{I}=0.03 n_{\text {OFM }}-0.63
$$

where;

$\lambda_{i}$ : Thermal conductivity of the Icelandic basalt and $n_{O F M}$ : opaque and ferromagnetic minerals volume proportion.

$$
\lambda_{m}=0.05 n_{\text {OFM }}-0.06
$$

$\lambda_{m}$ : Thermal conductivity $\left(\mathrm{W} \cdot \mathrm{m}^{-1} \cdot \mathrm{K}^{-1}\right)$ of Harrat basalt and $n_{O F M}$ : opaque and ferromagnetic minerals volume proportion.

In Figure 6 a general trend of the continental basalt i.e.: Jordanian Harrat, $\mathrm{Al}$ Hashimiyya basalt and the German basalt can be observed. On the other hand, the other type of basalt which represents the oceanic genesis has another trend in a different zone in this chart. This method could be a prospective approach for predicting thermal conductivity from some mineral phases presented in the basalts parallel with the rock genesis.

\section{Discussion}

Thermal conductivity of the crystalline rocks is highly dependent on the crystal type, crystal geometry and size [7]. In addition, it is independent of porosity (for vesicular basalt), if the porosity is less than 35\% [29]. The reported basalt values for thermal conductivity are within the range typical for basalts ([29]; [30]; [31]; [32]).

The samples two main clustered areas; upper and lower. It was found that the samples are of two categories according to their petrographic characteristics. This helps to interpret the relationship between thermal conductivity and mineral constituents as well as the intra-structures. Micro-fractures, crystals size, crystal alteration as well as crystal shape control thermal conductivity. The studied basaltic mineral composition is microscopically isotropic and homogeneous. Moreover, crystal imperfections (corrosion, auto-magmatic alteration, assimilation, hydrothermal fluid exchange and weathering) significantly decrease the thermal conductivity of the mineral phases. Minerals themselves have unique thermal conductivities, dependent of the chemical composition and physico-crystallographic properties [33]. It has been found that as the pyroxene crystals enlarged $(>3 \mathrm{~mm})$, then the thermal conductivity increases. Olivine volume proportion in the groundmass affects thermal conductivity, too. As olivine proportion increases then the thermal conductivity has been found tom be increased. 
In addition, the size of plagioclase crystals does not affect thermal conductivity of studied basalt. In order to determine the influence of crystal size distribution on thermal conductivity more precisely, further research will be necessary [7]. As shown, including more precise structural and textural studies (optical texture microscopy) a better discussion is possible, but a more systematic investigation is needed and additional Microprobe and XRD data. It was found that the upper sub-flows contains less altered crystals, thus it had been found that thermal conductivity for the lower sub-flow are higher of than the higher one. It can be predicted, as $\mathrm{Al}$ Hashimiyya basalts are the most recent in the region, that the older Harrat basalts have higher thermal conductivity than Al Hashimiyya. The crystals freshness (weathering competence) increases the influence on thermal conductivity [33].

Slight differences were observed regarding fracture microstructure and vesicle shape within the studied flow.

Here, a more reliable prediction method was developed. It can be concluded that the thermal conductivity is directly proportional to opaque and ferromagnetic mineral volume proportions (Equation (2)). Other parameters such as crystal boundaries, spacing and contact type should also be taken into account. Undoubtedly, these parameters play an important role in controlling thermal conductivity of the basalts ([7]; [29]). However, at this stage, the evaluation of the influence of these parameters cannot be performed precisely, and therefore presents a need for further investigation.

\section{Conclusion}

Thermal conductivity prediction from mineral proportions has become an additional tool for reservoir exploration methods that produces conservative results. The presented data of mineral composition allows us to propose a concept for predicting thermal conductivity. The reservoir thermophysical parameters are strongly influenced by the opaque and ferromagnetic minerals volume proportion and thus, define the performance of geothermal reservoir characters. Eventually, the reservoir mineralogy influences geothermal field development. Ongoing investigations include efforts to characterize mineral paragenesis based on crystal boundaries, contacts and spacing and resulting influence on the thermophysical reservoir properties. Such results indicate that the type of crystal contacts seems to be of similar importance as mineral proportion.

\section{Conflicts of Interest}

The author declares no conflicts of interest regarding the publication of this paper.

\section{References}

[1] Sass, J.H., Lachenbruch, A.H. and Monroe, R.J. (1971) Thermal Conductivity of Rocks from Measurements on Fragments and Its Application to Heat Flow Deter- 
minations. Journal of Geophysical Research, 76, 3391-3401.

https://doi.org/10.1029/JB076i014p03391

[2] Tester, J.W., Drake, E.M., Golay, M.W., Driscoll, M.J. and Peters, W.A. (2005) Sustainable Energy—Choosing among Options. MIT Press, Cambridge, MA.

[3] Wang, L.W., Tamainot-Telto, Z., Metcalf, S.J., Cristoph, R.E. and Wang R.Z. (2010) Anisotropic Thermal Conductivity and Permeability of Compacted Expanded Natural Graphite. Applied thermal Engineering, 30, 1805-1811.

https://doi.org/10.1016/j.applthermaleng.2010.04.014

[4] Singh, T.N., Sinha, S. and Singh, V.K. (2007) Prediction of Thermal Conductivity of Rock through physic-Mechanical Properties. Building and Environment, 42, 146-155. https://doi.org/10.1016/j.buildenv.2005.08.022

[5] Abdulagatova, Z., Abdulagatov, I.M. and Emirov, V.N. (2009) Effect of Temperature and Pressure on the Thermal Conductivity of Sandstone. International Journal of Rock Mechanics and Mining Sciences, 46, 1055-1071. https://doi.org/10.1016/j.ijrmms.2009.04.011

[6] El Sayed, A.M.A. (2011) Thermophysical Study of Sandstone Reservoir Rocks. Journal of Petroleum Science and Engineering, 76, 138-147.

https://doi.org/10.1016/j.petrol.2011.01.001

[7] Jessop, A.M. (2008) Models of Thermal Conductivity of Crystalline Rocks. International Journal of Earth Sciences, 97, 413-419. https://doi.org/10.1007/s00531-007-0214-y

[8] Andolfsson, T. (2013) Analyses of Thermal Conductivity from Mineral Composition and Analyses by Use of Thermal Conductivity Scanner: A Study of Thermal Properties of Scanian Rock Types. Dissertations in Geology at Lund University, 84 p.

[9] Pasquale, V., Gola, G., Chiozzi, P. and Verdoya, M. (2011) Thermophysical Properties of the Po Basin Rocks. Geophysical Journal International, 186, 69-81. https://doi.org/10.1111/j.1365-246X.2011.05040.x

[10] Hashin, Z. and Schtrickman, S. (1962) A Variational Approach to the Theory of Effective Magnetic Permeability of Multiphase Materials. Journal of Applied Physics, 33, 3125-3131. https://doi.org/10.1063/1.1728579

[11] Zimmerman, R.W. (1989) Thermal Conductivity of Fluid Saturated Rocks. Journal of Petroleum Science and Engineering, 3, 219-227. https://doi.org/10.1016/0920-4105(89)90019-3

[12] Robertson, E.C. and Peck, D.L. (1974) Thermal Conductivity of Vesicular Basalt from Hawaii. Journal of Geophysical Research, 79, 4875-4888. https://doi.org/10.1029/JB079i032p04875

[13] Bender, F. (1974) Geology of Jordan. Natural Resources Authority and German Geological Mission in Jordan Hanover, Germany.

[14] Al-Kharabsheh, A. and Al-Malabeh, A. (2002) Water Harvesting in Wadi Al-Maghyer, Azraq Basin-Jordan and Its Environmental Impacts. Proceeding in Congress in Urban Developments in Arid Region \& Associated Problems, 3, 97-106.

[15] Griffiths, C.M., Brereton, N.R., Beausillon, R. and Castillo, D. (1992) Thermal Conductivity Prediction from Petrophysical Data: A Case Study. Geological Society, London, Special Publications, 65, 299-315. https://doi.org/10.1144/GSL.SP.1992.065.01.23

[16] Franzson, H., Guðlaugsson, S. and Friðleifsson, G.Ó. (2001) Petrophysical Properties of Icelandic Rocks. Proceedings of the 6th Nordic Symposium on Petrophysics, 
15-16 May 2001, Trondheim, 1-14.

[17] Macdougall, J.D. (1988) Continental Flood Basalts and MORB: A Brief Discussion of Similarities and Differences in their Petrogenesis. In: Macdougall, J.D., Ed., Continental Flood Basalts, Springer, Dordrecht, Vol. 3, 331-341.

https://doi.org/10.1007/978-94-015-7805-9_10

[18] Al-Malabeh, A. (1993) The Volcanology, Mineralogy and Geochemistry of Selected Pyroclastic Cones from NE-Jordan and Their Evolution for Possible Industrial Applications. Ph.D. Thesis, Erlangen University, Erlangen.

[19] Van den Boom, G. and Sawwan, O. (1966) Report on Geological and Petrological Studies of the Plateau Basalts in NE Jordan. Germ. Geol. Missionin, Amman, 42.

[20] Hunting Technical Services Ltd., Macdonald, S.M. and Partners (1965) Wadi Dhuleil Investigation. Unpubl. Report, Herts, London.

[21] Ilani, S., Harlavan, Y., Tarawneh, K., Rabba, I., Weinberger, R., Ibrahim, K.M., Peltz, S. and Steinitz, G. (2001) New KAr Ages of Basalts from the Harrat Ash Shaam Volcanic Field in Jordan: Implications for the Span and Duration of the Upper Mantle Upwelling Beneath the Western Arabian Plate. Geology, 29, 171-174. https://doi.org/10.1130/0091-7613(2001)029<0171:NKAAOB>2.0.CO;2

[22] Abu Qudaira, M. (2004) The Geology of Zarqa Area, Bulletin 58. Natural Resources Authority, Amman, $47 \mathrm{p}$.

[23] Al-Zyoud, S. (2012) Geothermal Cooling in Arid Regions: An Investigation of the Jordanian Harrat Aquifer System. Ph.D. Thesis, Technische Universität Darmstadt, Darmstadt, $136 \mathrm{p}$.

[24] Popov, Y., Pribnow, D., Sass, J., Williams, C. and Burkhardt, H. (1999) Characterization of Rock Thermal Conductivity by High-Resolution Optical Scanning. Geothermics, 28, 253-267. https://doi.org/10.1016/S0375-6505(99)00007-3

[25] Streckeisen, A. (1974) Classification and Nomenclature of Plutonic Rocks: Recommendations of the IUGS Subcommission on the Systematics of Igneous Rocks. Geologische Rundschau, 63, 773-785. https://doi.org/10.1007/BF01820841

[26] Le Maitre, R.W., et al. (2002) Igneous Rocks: A Classification and Glossary of Terms. Cambridge University Press, Cambridge. https://doi.org/10.1017/CBO9780511535581

[27] Al-Malabeh, A. and Kempe, S. (2009) Petrolithology of the Permian Melaphyre lavas, Darmstadt, Germany. Neues Jahrbuch für Geologie und Paläontologie, 252, 129-143. https://doi.org/10.1127/0077-7749/2009/0252-0129

[28] Hughes, C. (1982) Igneous Petrology. Elsevier Scientific Pub. Co., New York, 551 p.

[29] Petrunin, S.I., Popov, V.G. and Ladygin, V.M. (2001) Thermal Properties of Basalts from the Bouvet Triple Junction and Their Implications for Petrophysical Characterization. Physics of the Solid Earth, 37, 441-451.

[30] Clauser, C. (1992) Permeability of Crystalline Rocks. EOS, Transactions American Geophysical Union, 73, 237-238. https://doi.org/10.1029/91EO00190

[31] Pasquale, V., Verdoya, M., Chiozzi, P., Cabella, R. and Russo, D. (1997) Thermophysical Properties of the Lipari Lavas (Southern Tyrrhenian). Annals of Geophysics, 6, 1493-1503.

[32] Iturrino, G., et al. (2000) Permeability, Electrical and Thermal Properties of Sulfide, Sedimentary, and Basaltic Units from the Bent Hill Area of Middle Valley, Juan de Fuca Ridge. Proceedings of the Ocean Drilling Program, Scientific Results, 169, 1-42. https://doi.org/10.2973/odp.proc.sr.169.115.2000

[33] Clauser, C. and Huenges, E. (1995) Thermal Conductivity of Rocks and Minerals. 
In: Ahrens, T.J., Ed., Rock Physics and Phase Relations-A Handbook of Physical Constants, American Geophysical Union, Washington, Vol. 3, 105-126.

https://doi.org/10.1029/RF003p0105 